\title{
Global Warming Every 1,500 Years: Implications for an Engineering Vision
}

\section{Dennis T. Avery}

ABSTRACT: This paper presents a counterpoint to the claim that $\mathrm{CO}_{2}$ and other "greenhouse gases" are the cause of warming trends in the global climate. The author presents a summary of the evidence that there are historical, geological, and biological records, as well as other indicators of a natural longer-term cycle in global temperature trends. Despite this, the claim that the effects of global warming are entirely benign is not made; rather, there are aspects of this paper that should inform decisions regarding. proposed technological and engineering solution. In particular, the implications for engineering leadership is the concept of choosing adaptive "no-regrets" technologies applied to address the inevitable trends of global climate change. Several of the measures described in this paper are the same as those proposed on the basis of global warming. caused by emissions of greenhouse gases. These include reducing dependence on fossil fuels, greater efficiency and transportation, energy-efficient buildings, and planning for changes in rainfall and drought patterns affecting the availability of water supply.

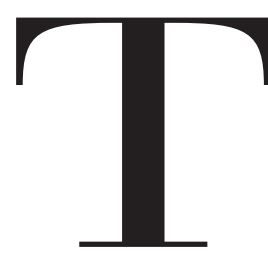

his paper presents a counterpoint to the claim that $\mathrm{CO}_{2}$ and other "greenhouse gases" are the cause of warming trends in the global climate: that is, there is no evidence that human-emitted $\mathrm{CO}_{2}$ has actually raised the earth's temperatures significantly. This paper is a summary of evidence by many researchers compiled by Singer and Avery (2007) in Unstoppable Global Warming: Every 1,500 Years, wherein we cite studies by more than 450 peer-reviewed authors and co-authors who have found reason to doubt the "global warming consensus."

We show the current global warming to be part of a natural trend with a cycle that results in elevated climatic tempera- tures every 1,500 years. That means humanity's response must be keyed to adaptation, not prevention. The measures that engineers should be taking to address global warming should be informed by the logic and history of this longer-term trend instead of only a focus on reducing $\mathrm{CO}_{2}$ and other emissions.

\section{QUESTIONING THE EVIDENCE}

It is proposed that no one can diagnose a climate change on the basis of a mere twenty-five years of data. Climate events are too long-term, and the short-term events are too complex. The proponents of greenhouse gas climate warming say that our recent warming must be caused by humans, since nothing else would account for the strong warming from 1976 to the present. How- 
ever, there was an equally strong global warming surge from 1916-1940, before global industrialization and auto numbers began to emit $\mathrm{CO}_{2}$ in serious amounts.

The earth's net global warming since 1940, moreover, has been a barely measurable $0.2^{\circ} \mathrm{C}$ over seventy years. From 1940 to 1975 , global temperatures actually trended down, while $\mathrm{CO}_{2}$ emissions were soaring. The proponents blame this cooling on sulfate particle pollution from power plants, which they claim masked some of the incoming solar radiation. If that were true, however, the southern hemisphere should have warmed faster than the northern hemisphere. In fact, the temperatures rose fastest right were the power plants were located-in the northern hemisphere.

The evidence we have is a warming trend, which began about 1850 , and mostly occurred too early to be blamed on human-emitted greenhouse gases. The total warming from 1850 to the present has been $0.7^{\circ} \mathrm{C}$, but $0.5^{\circ}$ of the warming occurred before 1940. Eighty percent of humanity's greenhouse gas emissions came after that date.

\section{The Historical Record}

There is evidence from the historical record that we are dealing with a cycle too moderate and long-term to be discerned by primitive peoples without thermometers or written records. The following summaries provide support of this statement and a perspective for how climate changes in the past can inform decisions for the future. Detailed references are provided in Singer and Avery (2007).

\section{Ancient Chinese Records}

China's written records go back further than those of any other country. China's climate from $1000 \mathrm{BC}$ to $1400 \mathrm{AD}$ has been reconstructed from palace records, official histories, and diaries. Key indicators include the arrival dates of migrating birds, the distribution of plant species and fruit orchards, patterns of elephant migrations, and the major floods and droughts. G. Yu of the Chinese National Academy of Science concludes that Chinese temperatures must have been $2-3^{\circ} \mathrm{C}$ higher than present during the Holocene warming six thousand years ago.

Also, Chinese wealth rose steadily from $200 \mathrm{BC}$, peaked about $1100 \mathrm{AD}$, and then entered a prolonged decline, according to Chao's (1986) careful economic analysis. Chao also reports that China averaged less than four major floods per century during the Medieval Warming and twice that many during the Little Ice Age. Major droughts were only one-third as common during the warm centuries as during the cold phases (the unnamed cold period before $200 \mathrm{BC}$, the Dark Ages from about 200 to 800 AD, and the Little Ice Age from about 1300 to $1850 \mathrm{AD})$.
British Wine Grapes

Wine grapes are one of our important climate proxies because people have always grown wine whenever and wherever they could. The Romans wrote of growing wine grapes in England in the first century when they occupied that island. They also wrote of wine grapes and olive trees gradually being cultivated farther and farther north in Italy. It seems clear that the climate was warming during the first century. Then the Romans left Britain, and the world entered the Dark Ages, when it was apparently too cold to grow wine in Britain.

In the eleventh century, the Britons themselves were growing wine grapes. William the Conqueror's tax collectors had nearly fifty vineyards on the tax rolls of the Domesday Book, which was assembled in 1086 by the tax collectors. After 1300, however, the European climate shifted to a cold phase and for 550 years no wine grapes were grown on the island. Londoners held ice festivals on the frozen Thames instead.

The next time British wine grapes matured was not until after 1950. Britain currently has about four hundred vineyards, but almost all of them are of the hobby type. The British wine industry's Web site says the vintners get only about two good years out of ten, but the rising global thermometers are giving them hope for the future. They also benefit from some hybrid grapes that the Romans didn't have.

The Greenland Vikings

Another eloquent testimonial to the existence of a long and natural climate cycle comes from Greenland. Eric the Red led a group of Viking settlers there from Iceland in 982 AD. They called it Greenland because the coastal regions were then bright green with grass. They pastured their dairy cattle and thrived for at least three hundred years on milk, cheese, vegetables, seal meat, and codfish. Eric's son Leif even ventured to Newfoundland in search of timber, but the natives' arrows drove him away.

Then the sea ice began to move south. The codfish moved south too, away from Greenland. The summers got shorter, making it harder and harder to grow enough hay for the cattle during the lengthening winters. Eventually, the sea ice and worse storms cut Iceland off from Greenland for a long 350 years. The last written record of its three thousand inhabitants was a wedding in 1408. The Greenland Vikings starved or froze due to climate change (Fagan 1999).

\section{The GeOlogic Record}

\section{Ice Cores}

In 1983, with the retrieval of the world's first long ice cores from the Greenland ice sheet, Willi Dansgaard of Denmark and Hans Oeschger of Switzerland were anxious to learn 
what the ice could tell us about the earth's temperature history. They had learned that the oxygen isotopes in the ice layers revealed the air temperature when the ice was laid down through the ratio of $0^{18}$ "heavy isotopes" to $0^{16}$ "light isotopes," which evaporate at different rates.

Dansgaard and Oeschger had expected to see the long ninety-thousand-year Ice Ages in the ice layers, and they did. What they had not expected was a long, moderate, 1,500year climate cycle. The cycle was very regular during the Ice Ages, at 1470 years, plus or minus ten years. It is somewhat more erratic during the warm interglacial periods, but still dominated the earth's temperatures over the past twelve thousand years (Dansgaard and Oeschger 1984). The cycle is abrupt, which argues for an external source. Dansgaard and Oeschger suspected the sun, partly because that's where most of our heat comes from, and partly because the "solar isotopes" - carbon 14 in trees and beryllium 10 in iceshowed the same cycles.

Within a few years after Dansgaard and Oeschger, a team led by France's Claude Lorius brought up an even longer ice core from the Antarctic, at the other end of the earth; and it, too, showed the 1,500-year climate cycle extending back nearly a million years (Lorius et al. 1985). Dansgaard, Oeschger, and Lorius shared the 1996 Tyler Prize (the "environmental Nobel").

\section{Seabed Sediments}

Researchers have found physical evidence of the 1,500-year climate cycle in the seabed sediments of at least nine oceans based mostly on the number and variety of the plankton fossils found in the layers. Gerard Bond of Columbia University's Lamont-Doherty Earth Observatory found it in icerafted rocky debris from Canada and Greenland, deposited in the North Atlantic (Gerard et al. 2001). Peter deMenocal of Lamont-Doherty found it in the plankton fossils of the South Atlantic, off West Africa (DeMenocal 2000). Lloyd Keigwin (1996) found the 1,500-year cycle from a carbon-dated seabed core in the Caribbean.

Lake Levels

Water levels of the Great Lakes show a strong response to the 1,500-year climate cycle, with the lake levels high during the climate coolings and low during warming periods. Todd Thompson of Indiana University and Steve Baedke of James Madison University constructed their lake-level history from the "strandplains" - shore-parallel sand ridges that have a core of water-laid sediment (Thompson and Baedke 1999).

Cave Stalagmites

On the Arabian Peninsula, a stalagmite showed a precise record of the 1,500-year climate cycle in the monsoon rainfall of Arabia, the African Sahel, and India. The stalagmite's cycles were also in phase with the temperature fluctuations of the Greenland ice cores twelve thousand years ago; but since the disappearance of the northern ice sheets, the cycle has been governed by solar activity instead (Neff et al. 2001). A New Zealand stalagmite showed exceptionally warm temperatures from 1200 to 1400, and extreme cold from 1600 to 1700 "in the Southern Hemisphere and a region meteorologically separated from Europe" (Wilson et al. 1979).

\section{THE Biologic RECORD}

Clearly documented higher temperatures than today during the Holocene Warmings from eight thousand and five thousand years ago undercuts the idea that the trees and plants and birds and bees won't be able to adapt. Following is a sampling of the biological evidence to support past changes in the earth's climate.

\section{Fossil Pollen}

The North American Pollen Database shows nine complete reorganizations of our trees and plants during the last fourteen thousand years - in a 1,500-year rhythm (Viau et al. 2002). The most recent started about six hundred years ago, culminating in the Little Ice Age, with maximum cooling three hundred years ago. The previous shift culminated in the maximum warming of the medieval warm period one thousand years ago. In Spain, pollen analysis from three thousand years of sediments in the Ria de Vigo shows three cold periods alternating with three warm ones.

\section{Ancient Tree Rings}

U.S. Forest Service researchers analyzed long-dead trees that grew above the current treeline on California's Whitewing Mountain, and concluded that temperatures must have been $3.2^{\circ} \mathrm{C}$ warmer when they were killed by volcanic gases in 1350 (Millar 2006). In the southern Sierra Nevada Mountains, foxtail pine and western juniper tree rings indicate a Medieval Warming from 1100 to 1375 , and a cold period from 1450 to 1850 . Tree rings from the long-lived bristlecone pines correlate statistically from 800 to the present "with the temperatures derived from central England" (LaMarche 1974).

\section{Crop Remains}

In southern Africa, carbon-dated crop remains prove the climate of the region must have been both warmer and wetter during the Medieval Warming from about 900 to 1300 (Huffman 1996).

Insects

In the north of England, archeologists found that the nettle groundbug thrived in the city of York in both Roman and 
Medieval times. Its typical habitat today is on stinging nettles in the much-warmer south of England (Lamb 1982).

Human Tooth Enamel

On Greenland, the University of Michigan's Henry Fricke tested the tooth enamel of dead Vikings for oxygen isotopes. He documented a $1.5^{\circ} \mathrm{C}$ drop in temperatures from the colony's settlement to its extinction (Monastersky 1994).

\section{The Sun-Climate Connection}

People have known for some four hundred years that there is a direct connection between sunspots and the earth's temperatures. We've been counting the sunspots since Galileo made his first telescope, and we've known for centuries that the coldest period during the Little Ice Age occurred during the Maunder and Sporer sunspot minimums, when there were virtually no sunspots at all. Britain's William Herschel said in 1801 that the price of wheat was directly controlled by sunspots, since less rain fell in Britain when there were few sunspots.

Fifty years ago, we spoke of the "solar constant." However, we've found in recent years that there is a tiny variation: 0.1 percent in the sun's irradiance. We've also found that the number of sunspots and the length of the sunspot cycle, which ranges from eight to fourteen years, have a powerful correlation with subsequent changes in the earth's sea surface temperatures.

Richard Willson, of Columbia and NASA, reports that the sun's radiation has increased by nearly 0.05 percent per decade since the late 1970s, when satellites first made it possible to monitor the sun directly. He says he can't be sure that the trend of rising solar radiation goes back further than 1978, but that if this trend had persisted through the twentieth century, it would have produced "a significant component" of the observed global warming (Willson and Mordvinov 2003). Rodney Viereck of the NOAA Space Environment Center admits that natural climate variation could account for one-third of the recent global warming (Viereck 2001).

Henrik Svensmark of the Danish Space Research Institute offers a more powerful sun-climate hypothesis. Small variations in the sun's irradiance are amplified into significant climate changes on earth by at least two factors: (1) cosmic rays creating more or fewer of the low, cooling clouds that deflect solar radiance back into space; and (2) solar-driven changes in ozone chemistry in the stratosphere that simultaneously create more or less heating of the earth's lower atmosphere (Svensmark 1998).

\section{EXAGGERATED EFFECTS OF WARMING}

There is much exaggeration regarding the potential effects of global warming. The purpose of this section is to describe some of the mitigating factors not considered in the assessment of these effects.

Increased Human Deaths

One of the alarmist claims is that global warming would cause millions of extra human deaths - this despite the wellknown fact that cold is far deadlier to humans than heat. In fact, from 1979 to 1997, extreme cold killed roughly twice as many Americans as heat waves, according to Indur Goklany of the U.S. Interior Department (Goklany and Straja 2000). Moreover, heat waves are becoming less and less of a threat as air conditioning spreads. Heat-related mortality in twenty-eights U.S. cities dropped from forty-one per day in the 1960s to only 10.5 per day in the 1990s (Davis et al. 2000).

In the meantime, lots of people keep dying from heart attacks and high blood pressure, risks that are radically elevated by cold. In Germany, heat waves were found to actually reduce overall mortality, while cold spells led to a significant increase in deaths (Laschweski and Jendritzky 2002). The German authors say that the longer a cold spell lasts, the more pronounced are the excess deaths; further, the higher death rates persist for weeks.

What about malaria and yellow fever? All the mosquitoes need is a patch of sunlit water that stays warm for a few days to hatch their larvae. Wouldn't warmer climates favor the mosquitoes that spread them? How quickly we forget. Malaria was endemic all over the United States and Europe before it was eradicated by DDT and window screens after World War II.

Extreme Sea-Level Increases

Another claim is that the melting of Greenland and Antarctic ice will raise sea levels twenty to thirty feet. It's true that sea levels rise when ice melts. At the end of the last ice age, there was so much ice in glaciers and ice sheets that sea levels rose four hundred feet in about two thousand years. But note that this took two millennia — and happened at the end of a big ice age, when the forcing agent was the sun, not $\mathrm{CO}_{2}$. Instead of exaggerated sea level increases, the expectation should be for sea levels to keep rising at six inches per century.

Elephant seals are telling us that the frigid Antarctic has already had a thousand-year warming, which started during the Roman Empire and produced temperatures higher than today's. Even that long warming didn't melt the huge Antarctic ice mass or drown the world's coastal cities. Brenda Hall of the University of Maine reports carbon-dating bits of molted elephant seal skin and hair-and even mummified seal pups - left behind in past centuries on the raised beaches of Antarctica's Ross Sea. The region today is much too cold 
for elephant seals to molt or breed; they need ice-free beaches, and the Ross Sea shore is currently locked in ice year-round.

Hall and her research team conclude that the current retreat of the West Antarctic ice sheet may have been going on for thousands of years. It's likely to continue even without further human-emitted greenhouse gases, until the planet gets another Little Ice Age — or a big one (Hall 2006). John Stone of the University of Washington says it would take another seven thousand years to melt the Antarctic ice cap even with substantial warming (Stone et al. 2003). Another Little Ice Age, or a big one, is due long before that.

The Intergovernmental Panel on Climate Change says that the most vulnerable part of the Antarctic ice sheet (the Amundsen Sea Embayment) would take thousands of years to melt at present temperatures. Even doubling of its current outflow rates would add only $0.5 \mathrm{~mm}$ per year to sea level rise (Vaughn and Blankenship 2007).

Neils Reeh of the University of Denmark says there's "broad agreement" among sea level experts that another $1{ }^{\circ} \mathrm{C}$ of warming would melt enough of Greenland to raise sea levels by only about half an inch per year (Reeh 1999). Meanwhile, the Southern Ocean has warmed enough to produce snow over the Antarctic, so the East Antarctic Ice Sheet is adding about forty-five billion tons of ice per year-almost completely offsetting the Greenland meltwater.

\section{Fiercer Storms}

Storms are actually powered by the temperature differential between the poles and the equator. During a warming, the Polar Regions get four to six degrees warmer, and the equator doesn't — so there are fewer, weaker storms. Dozens of research studies document the lack of more or fiercer storms, including the entire June 2003 special issue of Natural Hazards. J. B. Elsner of Florida State University notes the British Navy recorded less than half as many major Caribbean hurricanes per decade during 1700-1850 (the end of the Little Ice Age) as we've recorded in the past fifty years of warming (Elsner et al. 2000).

\section{Death of Species}

No species have died due to rising temperatures yet, despite 150 years of what we're told was "unprecedented" warming. The Golden Toad of Costa Rica was a claimed overheating victim - but then we found that the ranchers who cleared the lower slopes of the toad's cloud-forest home had altered the cloud dynamics. Trees and vegetation are cold-limited but not heat-limited, so they're currently extending their ranges northward while also keeping their past habitat. Hundreds of studies worldwide have found that birds, bees, butterflies, mammals, snakes, and myriad other fauna are extending their ranges to keep pace, creating a richer biodi- versity in our forests than has existed over the past one thousand years (Parmesan and Yohe 2003). Experts from Environment Canada say that Ontario forests still have 30 percent less biomass than during the Medieval Warming (Campbell and McAndrews 1993).

Changes in Rainfall Patterns

The 1,500-year cycle typically produces a temperature change of four to five degrees Centigrade from peak to trough. Temperature changes are greater in the Arctic. At the equator, however, the temperatures don't change- the rainfall does. The tropical rain belts at the equator can move hundreds of miles north and south during the cycle. The Sahara may become wet enough to pasture cattle, even as Kenya and Cameroon undergo severe drought. California tree rings show two century-long droughts during the Medieval Warming and the southern tier of the United States showed persistent dryness, while Canada and Siberia became warmer and wetter.

\section{A “No-REgRETS" VISION}

\section{Adaptive Technology Choices}

Singer and Avery (2007) describe the concept of adaptive technology choices, and relate the story of one American, who when asked to name the greatest invention of the twentieth century, answered "insulation." He'd grown up in a poorly insulated nineteenth-century mountain ranch house and it was his job to cut the families' firewood. Insulation is cheap, safe, sustainable, and helps reduce energy departments whether the climate is warming or cooling. It is a fine "noregrets" technology of the "install-it-and-forget-it" variety. Most insulation is a good idea whether the climate changes much or not.

The vision for the engineering adaptations of infrastructure, energy generation, and energy use is proposed to be of a similar nature- no regrets in the future regarding the economic choices that are made today. There are certain measures such as an extreme reduction in the burning of fossil fuels that may sidetrack the world's economic growth. Also, there are technologies that may be very costly, such as carbon capture and sequestration, while the technical and institutional issues of long-term storage have not yet been fully developed. These are the types of measures that have a risk of high cost without necessarily having a substantial benefit if the greenhouse gas hypothesis is not the source of global warming.

Reducing Dependence on Fossil Fuels

Nevertheless, it is a good idea to reduce the world's dependence on fossil fuels. Even if we can use petroleum and gas, their proven reserves are long-term limited. The first shift in our thinking should probably be toward support of the 
nuclear power resurgence to provide the base power that has so far relied on coal and is ill suited to the erratic output of solar panels and wind turbines.

Dozens of new nuclear power plants are now being built and designed all over the world, especially in China and India. The new generation of nuclear plants is focusing on well-tested designs with passive safety systems that will be both safer and more efficient than our present plants. We should probably also use fast breeder reactors to make better use of the uranium and rhodium deposits, and to minimize the need for long-term storage of spent fuel. Storage designs have already offered ten-thousand-year safety, but we have lacked the political will to move ahead as long as fossil fuels were cheap.

\section{Greater Efficiency in Transportation}

We should also pursue greater efficiency in transportation fuels and modes, as well as the infrastructure to support public transit alternatives to reduce the trips by individuals driving automobiles. Hybrid cars will be increasingly useful. One biotechnology entrepreneur foresees biotech production of hydrogen (biologically freed from its oxygen molecules) — a massive energy breakthrough, if it can be achieved.

\section{Energy Efficient Buildings}

We will have a greater need for air conditioning and for heat-adapted building designs that will be more efficient and comfortable in moderately warmer climates. We will have a massive need for more water use efficiency not only in farming but in all other forms of our society's water use. I recently visited The Springs project in Las Vegas, which has just won an architectural award for its excellent use of terrain, wind catching, yard plantings, and computers to increase energy and water efficiency. We will need such developments on a much broader scale than ever before.

Preparing for Changes in Rainfall and Droughts

The climate of the Modern Warming won't be entirely benign. There will be severe droughts and some floods, and there will continue to be hurricanes and typhoons. We will have to roll with their punches. During the Medieval Warming, California had two century-long droughts that would have severely stressed a modern society. Such droughts may occur again, and we must be prepared to adapt. San Diego, for example, may become even dryer for long periods. That may mean the city will have to desalinate its drinking water, recycle its wastewater, and import much of its food from a newly warmer and wetter Canada. We'll need plans for desalination plants, and their energy sources. We may need to enhance the crop-production infrastructure in Canada, and tie it into the U.S. road and rail nets.
The whole southern tier of United States had a tendency toward drought in the Medieval Warming. If that occurs again, we may need to gradually shift cropping patterns northward, and produce more semiarid crops in Texas and Georgia. This will require extensive adaptation by the farmers and farming infrastructure. We're already seeing a northward shift in wine grape production-toward British Columbia's Okanagan Valley as an example, while the longfamed Napa Valley has to harvest its grapes at night to minimize grape losses.

\section{Population Migrations and Global Politics}

On an even more somber note, the tropical rain belts are likely to move northward by hundreds of kilometers in Africa-bringing unusual wetness to the Sahel, and leaving Kenya and Cameroon unusually dry. Should we relocate the people? Will there be more efficient ways for them to support themselves where they are now? This will take study and effective decision making based on a difficult mix of science and politics.

What will happen to the climate of the Middle East? How will it impact Moslem societies already stressed by unequal world incomes and broadening use of modern technologies? The problems might get easier to solve, but they also might not.

\section{The Engineering Challenge}

Our scientists have shown great enthusiasm in documenting global warming, and our media have demonstrated marvelous talents for mobilizing public opinion in support of efforts to mitigate that warming. Several of the measures proposed here are the same as those proposed on the basis of global warming caused by emissions of greenhouse gases. Now, the engineering professions must demonstrate their ability to adapt our societies to the less dramatic but equally pervasive challenge of implementing "no-regrets" technology solutions.

\section{REFERENCES}

Bond, G., et al. (2001). "Persistent solar influence on North Atlantic climate during the Holocene." Science, 294, 2130-136.

Campbell, I. D., and McAndrews, J. H. (1993). "Forest disequilibrium caused by rapid Little Ice Age cooling." Nature (London), 366, 336-338.

Chao, K. (1986). Man and land in China: An economic analysis, Stanford University Press, Stanford, Calif.

Dansgaard, W., and Oeschger, H. (1984). "North Atlantic climatic oscillations revealed by deep Greenland ice cores." Climate processes and climate sensitivity, F. E. Hansen and T. Takahashi, eds., Monograph 29, American Geophysical Union, Washington, D.C. 
Davis, R. E., et al. (2000). "Changing heat-related mortality in the United Sates." Environ. Health Perspect., 111, 1712-1718.

DeMenocal, P. (2000). "Coherent high- and low-latitude climate variability during the Holocene warm period." Science, 288, 2198-2202.

Elsner, J. B., et al. (2000). "Spatial variations in major U.S. hurricane activity: Statistics and a physical mechanism." J. Clim., 13, 2293-2305.

Fagan, B. (1999). Floods, famine, and emperors, Chapter 10, Basic Books, New York.

Goklany, I., and Straja, S. R. (2000). "U.S. trends in crude death rates due to extreme heat and cold ascribed to weather, 1979-1997." Technology, 7S, 165-173.

Hall, B. L. (2006). "Holocene elephant seal distribution implies warmer-than-present climate in Ross Sea." Proc. Natl. Acad. Sci. U.S.A., 103, 10213-10217.

Huffman, T. (1996). "Archeological evidence for climatic change during the last 200 years in Southern Africa." Quaternary International, 33, 55-60.

Keigwin, L. (1996). "The Little Ice Age and Medieval Warm Period in the Sargasso Sea." Science, 274, 503598.

LaMarche, V. (1974). "Paleoclimatic inferences from long tree ring records." Science, 183, 1040-1048.

Lamb, H. H. (1982). Climate history and the modern world, Oxford University Press, London, p. 181.

Laschweski, G., and Jendritzky, G. (2002). "Effects of the thermal environment on human health: An investigation of 30 years of daily mortality data from SW Germany." Clim. Res., 21, 91-103.

Lorius, C., et al. (1985). "A 150,000-year climatic record from Antarctic Ice.” Nature (London) 316, 591-96.

Millar, C. (2006). "Late Holocene forest dynamics, volcanism, and climate change at Whitewing Mountain and San Joaquin Ridge, Mono Country, Sierra Nevada, CA, USA." Quaternary Research, 66, 273-287.

Monastersky, R. (1994). "Viking teeth recount sad Greenland tale." Sci. News (Washington, D. C.), 219, 310.

Neff, U., et al. (2001). "Strong coherence between solar availability and the monsoon in Oman between nine and six kyr ago." Nature (London), 411, 290-293.

Parmesan, C., and Yohe, G. (2003). "A globally coherent fingerprint of climate change impacts across natural systems." Nature (London), 421, 37-42.

Reeh, N. (1999). "Mass balance of the Greenland ice sheet: Can modern observation methods reduce the uncertainty?" Geografiska annaler, 81A, 735-42.

Singer, S., and Avery, D. T. (2007). Unstoppable global warming: Every 1,500 years, Rowman \& Littlefield, Lanham, Md.

Stone, J., et al. (2003). "Holocene deglaciation of Marie Byrd Land, West Antarctica.” Science, 299, 99-102.

Svensmark, H. (1998). "Influence of cosmic rays on earth's climate." Danish Meteorological Institute, Phys. Rev. Lett., 81, 5027-5030.

Thompson, T. S., and Baedke, S. J. (1999). "Strandplain evidence for reconstructing Later Holocene lake levels in the Lake Michigan basin." Proc., Great Lakes Paleo-Levels Workshop: The Last 4,000 Years, C. Sellinger and F. Quinn, eds., Great Lakes Environmental Research Laboratory, U.S. Department of Commerce, Ann Arbor, Mich.

Vaughn, D., and Blankenship, D. (2007). "West Antarctic links to sea level estimation." EOS Trans. Am. Geophys. Union, 88, 48-46.

Viau, A. E., et al. (2002). "Widespread evidence of 1,500year climate variability in North America during the past 14,000 years." Geology, 30, 455-458.

Viereck, R. (2001). "The sun-climate connection.” NOAA Space Environment Center, online: 〈http://www. research.noaa.gov/spotlite/archive/spotsunclimate.html $\rangle$ (accessed March 2007).

Willson, R., and Mordvinov, A. V. (2003). "Secular total solar irradiance trends during solar cycles 21-23." Geophys. Res. Lett., 30, 1199.

Wilson, A. T., et al. (1979). "Short-term climate change and New Zealand temperatures during the last millennium." Nature (London), 279, 315-317.

Dennis Avery is a researcher at the Hudson Institute, a public policy research institute.

UME
This article appears in "Engineering Strategies for Global Climate Change," a special
issue of Leadership and Management in Engineering, Volume 8, Issue 3 (July 2008)
published by the American Society of Civil Engineers (ASCE). Copies of the entire
$73-$ page, special issue are available through ASCE ( $\$ 30.00+$ shipping) by contacting
1-800-548-2723, 1-703-295-6300 (Int'I), or visiting us online at http://pubs.asce.org.

American Society of Civil Engineers, 1801 Alexander Bell Drive, Reston, VA 20191 USA 